\title{
航空交通流管理における管制作業量についての一検討
}

\author{
住谷 美登里*・福島 幸子**福田 豊*

\section{A Study of a Controller Workload for Air Traffic Flow Management}

\author{
Midori SUMIYA、 Sachiko FUKUSHIMA and Yutaka FUKUDA
}

\begin{abstract}
ATFM (Air Traffic Flow Management) is introduced for safe and effective flight at each sector and to satisfy demand for air traffic increase. ATFM is conducted by "traffic management index" that represents a controller workload. This paper describes the relationship traffic conditions and the index based on parameter of controller workload at 15 sectors. The definition of parameter was based on the measurement, analysis and classification of the controller's task of each aircraft. It is time consuming to analyze controller's task.

Therefore, this paper proposes improved method that provides an index for ATFM without analyzing the controller's tasks. We propose methods for index based on the number of proximity aircraft. Then, the close relationship between the proposed index and the current index has been shown.

Keywords : Air Traffic Control、Air Traffic Flow Management、Controller Workload, Proximity aircraft キーワード：交通管制、航空交通流管理、管制作業量、近接機数

\section{1. はじめに}

近年、航空交通需要が増加してきている。そのた め、航空交通流管理 (ATFM : Air Traffic Flow Management）を実施し、安全かつ效率的な航空機 の運航、空域の有効利用を行っている。航空機は出 発から到着までいくつかの分割されたセクタよよば れる管制空域を通過する。この各々の管制空域にお いて航空管制官（以下、管制官）は、交通の安全と 円滑な流れを維持するため航空交通管制業務を行っ ている。ATFMに拀いて、各管制空域では安全で効 率的な運航をするために航空機の出発前に交通量の 指標値を予測計算し、規定值を超えると予測した場 合、出発時刻等の調整（管理）を行う。我が国では、 航空交通管理 (ATM) センタで、航空交通管制部の 全セクタおよび主要空港に対して ATFM が塞施さ れている。

我が国では ATFM で用いられている交通量の指 標として、2 種類の考え方が利用されている。1つ

めは、空域に航空機が何機存在できるか、という物 理的な值で、主要空港では、単位時間あたりの離着 陸可能機数を用いている。2 つめは、管制官の航空 管制業務の作業負荷を基本とする指標值で、航空路 管制セク夕に利用されている。

この作業負荷を基本とする指標值は、管制作業量 と呼ばれる。管制作業量とは、まず航空機の出発前 に各空域の飛行時間を求め、次に管制官の作業を表 す係数である管制負荷係数を重み付けして時間推移 を予测計算した值である。管制官は、その時々の天 候、交通量、パイロットの要求等を考慮して航空管 制業務を行っている。この航空管制業務を各空域で 計測、分類してあらかじめ管制負荷係数という係数 を設定する。各管制セクタの管制官による管制指示 等の航空管制業務の分析は、膨大な労力を要する。 また空域再編時は、交通流を設定し、管制官参加の 実時間シミュレーション実験等を実施して、管制作 業の分析が必要亡なる。
\end{abstract}

\begin{tabular}{llllll}
\hline$*$ & 正会員 & 独立行政法人 & 電子航法研究所 & （T182-0012 & 東京都調布市深大寺東町 7-42-23） \\
$* *$ & 非会員 & 独立行政法人 & 電子航法研究所 & (T182-0012 & 東京都調布市深大寺東町 7-42-23)
\end{tabular}


著者らは ATFM の指標値を求める力法の提案と して、管制官参加のシミュレーション実験を実施し、 セクタ内を飛行している各航空機の高度変更量に着 目した。管制作業を空域への入域、出域高度による 分類をして計算したが、分類方法にさらなる検討が 必要であることがわかった(1)。

今回は管制官の航空管制業務の作業分析をせずに 交通シミュレーションでより簡単に計算して ATFM の指標値を求めたい。そのために現行で求め るATFM の指標值である管制作業量と、実デー夕に よる交通状況を比較し、交通流から ATFM の指標值 を求める方法を提案する。交通流としてセク夕内で 近接する航空機数に着目したところ現行方法と相関 が見いだされた(3)。本稿では 15 セク夕において交通 状況と比較し、近接する航空機数に着目し、指標值 を求める方法を提案する。

まず、調查対象について述べる。次に現行の ATFM の指標として用いられている管制作業量の 求め方を説明する。そしてセクタごとの交通流と指 標値との関係を示す。更に近接する航空機数に着目 し、指標値を求める方法を提案する。

\section{2. 航空管制 \\ 2.1 航空管制業務}

国内の航空路管制セク夕を飛行する航空機の位置 を把握するために航空路監視レーダ（ARSR：Air Route Surveillance Rader) が国内に約 16 箇所設置 されている。これらのレーダで得られた航空機の位 置情報（レーダデータ）は 10 秒ごとに各航空交通 管制部のレ一ダ画面上に表示される。航空路管制セ クタを管制する管制官は、セクタ内を飛行している 航空機が効率よく安全に運航するよう、レーダ画面 を見て航空機の状況を監視する。そして管制官は航 空機（パイロット）と通信し、他の航空機と予め定 められた管制間隔（航空機間の最低間隔）を保つよ うに速度、高度、針路等の管制指示を出し、飛行経 路等が記載されている運航票に管制指示を記入する。 これが代表的な航空管制業務である。

\section{2 航空交通流管理}

各航空機は飛行前に飛行計画を提出する。飛行計 画はATM センタの飛行情報管理システム (FDMS : Flight Data Management System) にて管理されている。

ATM センタの飛行情報管理システムの飛行計画 情報には、通過予定地点名、各地点の通過予定時刻 や通過予定高度、出発・到着空港等が含まれている。 これを利用して各航空機の各セク夕の境界通過予定
時刻からセク夕内飛行時間を予測する。それをもと に ATFM の指標値を出発前に予測して出発時刻等 の調整を実施している。

\section{3. 調査対象}

\section{1 調查空域}

ATM セン夕では飛行計画情報をもとに飛行前に 管制作業量という指標値を予測して ATFM を実施 しているが、本稿では実際の飛行状況を把握するた め航跡データであるレーダデー夕を利用した。

レーダデータには、約 10 秒ごとの各航空機の位 置（緯度、経度）、高度、出発空港、到着空港、管制 セクタ名等の情報が含まれる。

2006 年 8 月 24 日 (木) の 00:00:00 から 23:59:59 （日本標淮時：JST）までに東京航空交通管制部の 15 セク夕(T01 から T27) を飛行した航空機を対象 とした。Fig.1に当時のセク夕の構成図を示す。

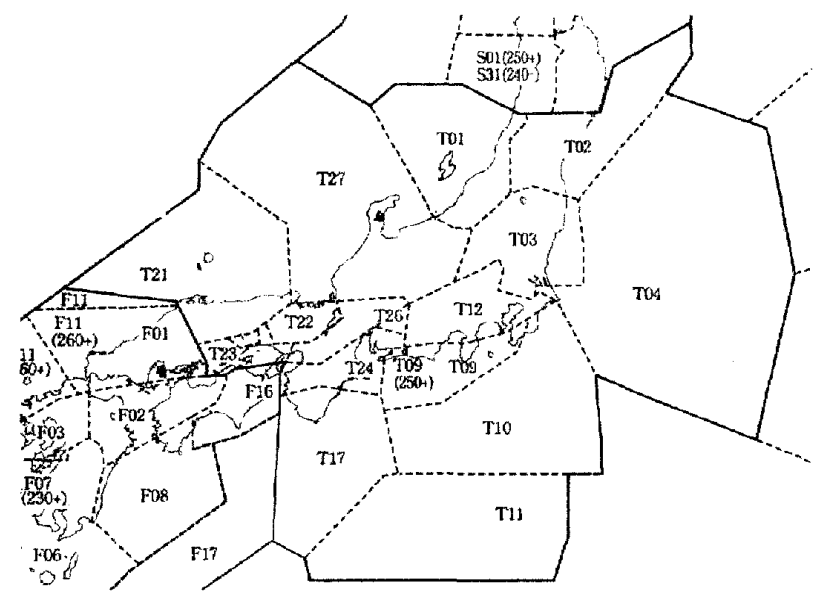

Fig.1 Geometry of sector configuration

\section{2 便数}

レーダデータより航空機 $\mathrm{a}_{\mathrm{i}}\{\mathrm{i}=1, \cdots, \mathrm{N}\}$ のセ クタへの入域時刻、セクタからの出域時刻をそれぞ 机 $\mathrm{IT}_{\mathrm{i}} 、 \mathrm{OT}_{\mathrm{i}}$ とする。通過時間 $\left(\mathrm{OT}_{\mathrm{i}}-\mathrm{IT}_{\mathrm{i}}\right)$ が 1 分以 下の便は、平均通過時間と比較して小さくレーダデ 一タのエラ一值と考えられるので今回の解析対象か ら外す。各セク夕通過便数亡各セク夕の通過時間 (Flight time) の平均值を Table1に示す。

Table 1 Number of aircraft and average flight time for each sector

\begin{tabular}{|l|l|l|}
\hline \multicolumn{1}{|c|}{ Sector } & $\begin{array}{l}\text { Number of } \\
\text { aircraft }\end{array}$ & $\begin{array}{l}\text { Average flight } \\
\text { time }\end{array}$ \\
\hline T01 (Joetsu) & 414 & $14 \mathrm{~m} 42 \mathrm{~s}$ \\
\hline T02 (Tohoku) & 400 & $9 \mathrm{~m} 48 \mathrm{~s}$ \\
\hline
\end{tabular}




\begin{tabular}{|l|l|l|}
\hline T03 (Kanto North) & 545 & $13 \mathrm{~m} 42 \mathrm{~s}$ \\
\hline T04 (Kanto East) & 340 & $26 \mathrm{~m} 45 \mathrm{~s}$ \\
\hline T09 (Kanto South A) & 633 & $14 \mathrm{~m} 18 \mathrm{~s}$ \\
\hline T10 (Kanto South B) & 395 & $14 \mathrm{m00s}$ \\
\hline T11 (Kanto South C) & 103 & $14 \mathrm{~m} 23 \mathrm{~s}$ \\
\hline T12 (Kanto West) & 618 & $12 \mathrm{~m} 33 \mathrm{~s}$ \\
\hline T17 (Kii) & 439 & $12 \mathrm{~m} 21 \mathrm{~s}$ \\
\hline T21 (Kinki West) & 421 & $16 \mathrm{~m} 54 \mathrm{~s}$ \\
\hline T22 (Sanyo) & 494 & $8 \mathrm{~m} 18 \mathrm{~s}$ \\
\hline T23 (Harima) & 302 & $8 \mathrm{~m} 37 \mathrm{~s}$ \\
\hline T24 (Mikawa) & 672 & $8 \mathrm{~m} 1 \mathrm{~s}$ \\
\hline T26 (Tokai) & 672 & $7 \mathrm{~m} 50 \mathrm{~s}$ \\
\hline T27 (Hokuriku) & 544 & $16 \mathrm{~m} 18 \mathrm{~s}$ \\
\hline
\end{tabular}

m:minute s:second

\section{3 管制機数}

ある時刻 $\mathrm{t}$ にセクタ内を飛行している航空機数 $\mathrm{CN}(\mathrm{t})$ 管制機数（Controlled aircraft）亡する。管 制機数を各航空機のセクタの入出域時刻より 1 分ご とに 24 時間分求めた。その管制機数の最大值亡平 均值を求め、Table2 に示す。1 日 (24 時間分) の 平均管制機数は、T04 (関東東) セクタが 6.33 便と 一番多い。これは、平均通過時間が長いためと考え られる。1 日の平均管制機数は通過便数と平均通過 時間の積に比例する。

Table 2 Number of controlled aircraft for each sector

\begin{tabular}{|l|l|l|}
\hline Sector & Max & Average \\
\hline T01 (Joetsu) & 20 & 4.20 \\
\hline T02 (Tohoku) & 12 & 2.71 \\
\hline T03 (Kanto North) & 17 & 5.19 \\
\hline T04 (Kanto East) & 18 & 6.33 \\
\hline T09 (Kanto South A) & 17 & 6.29 \\
\hline T10 (Kanto South B) & 15 & 3.83 \\
\hline T11 (Kanto South C) & 5 & 1.03 \\
\hline T12 (Kanto West) & 16 & 5.37 \\
\hline T17 (Kii) & 12 & 3.77 \\
\hline T21 (Kinki West) & 17 & 4.94 \\
\hline T22 (Sanyo) & 12 & 2.86 \\
\hline T23 (Harima) & 9 & 1.81 \\
\hline T24 (Mikawa) & 13 & 3.74 \\
\hline T26 (Tokai) & 13 & 3.65 \\
\hline T27 (Hokuriku) & 23 & 6.16 \\
\hline
\end{tabular}

\section{4. 現行の指標 \\ 4.1 管制作業量の求め方}

ATFMの指標值である管制作業量の求め力につい て説明する。ATFM の指標值である管制作業量

(Controller Workload) TASK $\mathrm{T}(\mathrm{t})$ は、i番目の航空 機 $a_{i}$ の時間区間 $[t, t+T]$ におるセク夕内の飛行時間 $\mathrm{ST}_{\mathrm{T}}(\mathrm{t}, \mathrm{i})$ 乙管制官の航空管制業務を表す管制負荷係 数 $\mathrm{C}_{\mathrm{ij}}$ を用いて

$$
\operatorname{TASK}_{\mathrm{T}}(\mathrm{t})=\sum_{\mathrm{i}=1}^{\mathrm{N}} \mathrm{ST}_{\mathrm{T}}(\mathrm{t}, \mathrm{i}) \mathrm{C}_{\mathrm{ij}}
$$

で表される。

ここで $\mathrm{i}$ 番目の航空機 $\mathrm{a}_{\mathrm{i}}$ の時間区間 $[\mathrm{t}, \mathrm{t}+\mathrm{T}]$ におけ るセク夕内の飛行時間 $\mathrm{ST}_{\mathrm{T}}(\mathrm{t}, \mathrm{i})$ は航空機 $\mathrm{a}_{\mathrm{i}}$ のセクタ の入域時刻 ITi、セク夕からの出域時刻 OT て (2)式のようになる。

$\mathrm{ST}_{\mathrm{T}}(\mathrm{t}, \mathrm{i})=\left\{\begin{array}{cc}\mathrm{OT}_{\mathrm{i}}-\mathrm{IT}_{\mathrm{i}} & \left(\mathrm{t}<\mathrm{IT}_{\mathrm{i}}, \mathrm{OT}_{\mathrm{i}}<\mathrm{t}+\mathrm{T}\right) \\ \mathrm{t}+\mathrm{T}-\mathrm{IT}_{\mathrm{i}} & \left(\mathrm{t}<\mathrm{IT}_{\mathrm{i}}<\mathrm{t}+\mathrm{T}<\mathrm{OT}_{\mathrm{i}}\right) \\ \mathrm{OT}_{\mathrm{i}}-\mathrm{t} & \left(\mathrm{IT}_{\mathrm{i}}<\mathrm{t}<\mathrm{OT}_{\mathrm{i}}<\mathrm{t}+\mathrm{T}\right) \\ \mathrm{T} & \left(\mathrm{IT}_{\mathrm{i}}<\mathrm{t}, \mathrm{t}+\mathrm{T}<\mathrm{OT}_{\mathrm{i}}\right) \\ 0 & \text { other }\end{array}\right.$

一方管制負荷係数 $\mathrm{C}_{\mathrm{ij}}$ は、各セクタの航空機（i） の分類（j）に応じて設定する。各航空機の出発、到 着空港に応じて出発機（departure）、到着機 (arrival)、通過機 (over-flight)、域内機 (in-sector) の 4 つに分類される。これは各セクタの管制作業に 必要な時間がこれら 4 種類に属するためである。

ATFM では、 $\mathrm{T}=30$ 分亡して時間推移の $\mathrm{TASK}_{\mathrm{T}}(\mathrm{t})$ を求める。30 分間に作業可能な上限值（1800s：容 量）を超えるとATM センタは出発遅延等の調整を 行う。

\section{2 管制作業を表す係数}

管制作業時間を分析・分類して、平均值に基づい て前もつて管制負荷係数を定める。管制作業に必要 な時間とは、航空機に対して、通信設定や、高度・ 速度・方位等を指示するための通信時間や考慮時間、 運航票の記大等の作業時間のこしである。各セクタ の分類された各係数值を Fig.2 に示す(2)。

この図から、各分類の係数值はセクタごとに大幅 に異なっていることがわかる。特に到着機の管制負 荷係数值は他の分類の係数值より大きめである。こ れは、到着機に対する管制作業時間が他より多いこ とを示している。 


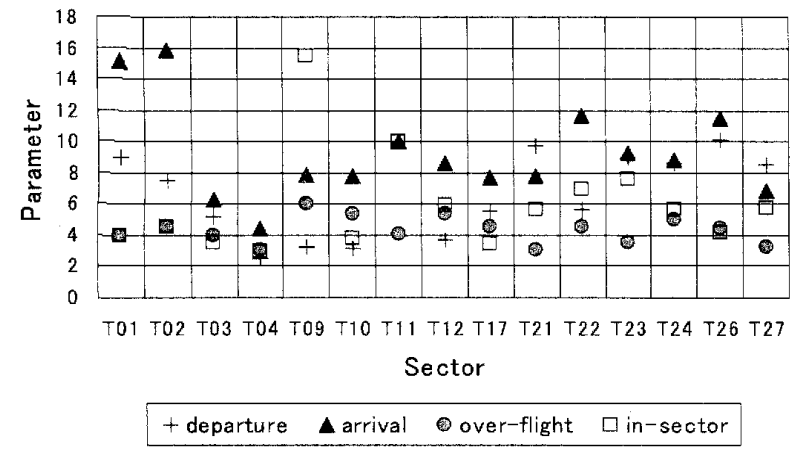

Fig.2 Parameters classified by category for each sector

\section{3 分類}

各セクタの航空機を、第 4.2 節のような種類で分 類した便数を Fig.3に示す。各航空機の出発、到着 空港と各セクタの空港によって分類を行う。例えば T01 セクタでは、庄内、新潟、佐渡の各空港を出発 している航空機は出発機、この 3 空港を到着空港と している航空機は到着機、この 3 空港を出発し、到 着する航空機を域内機、その他を通過機とする。

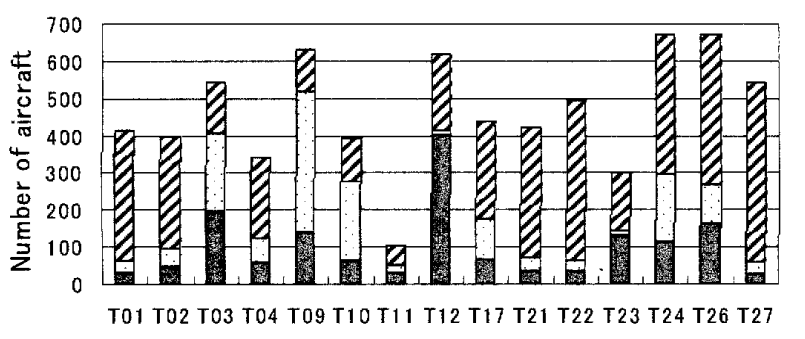
Sector

departure $\square$ arrival $B$ over-flight $\mathbf{D}$ in-sector

Fig. 3 Number of aircraft classified by each category and each sector

出発機の割合が最も多いセク夕はT12（関東西） セクタである。T12 セク夕は羽田空港から出発する 便が通過するセクタなので出発機の割合が多い。 $\mathrm{T} 12$ セク夕の出発機は全体の $65 \%$ を占めている。 T09（関東南 A)、T10（関東南 B）セク夕は羽田空 港へ到着する便が通過するセクタなので到着機の割 合が多い。T03 (関東北) セク夕は、出発機、到着 機、通過機の割合はほぼ同等である。その他のセク 夕は通過機の割合が多い。

\section{4 指標值}

$\mathrm{ATFM}$ では、 $\mathrm{T}=30$ 分として時間推移の $\mathrm{TASK}_{\mathrm{T}}(\mathrm{t})$ を求める。 $\mathrm{T}=30$ 分、 $\mathrm{t}$ を 10 分おきに(1)式より管制 作業量という指標値を求める。例として T01 (上越) セクタの指標値を Fig.4の棒グラフで示す。

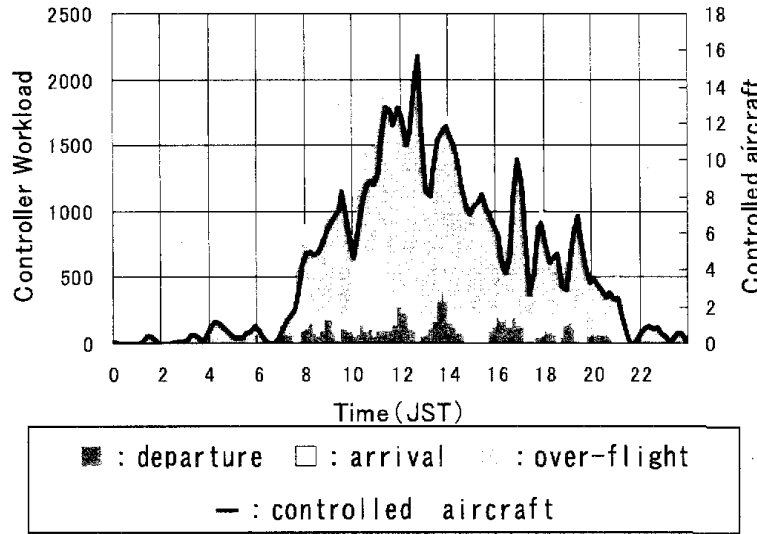

Fig.4 Current index (controller workload) and average number of controlled aircraft in 30 minutes

(T01 sector)

ATFMではセクタ内飛行時間を予測して管制作業 量という指標值を求めている。各時刻における指標 值が容量（1800）を超えている場合は、容量を超え ないように出発前に出発遅延等で調整してから飛行 することになっている。しかし、セクタの入出域時 刻は出発前の予測と実際の運航では異なることもあ るので、本稿のように運航後のデー夕をもとに指標 值を求めると、容量を超えることもある。

\section{5 平均管制機数と指標值との関係}

交通流の時間推移と比較するために(3)式で求め られる $\mathrm{T}$ 分間の平均管制機数と比較する。

$$
\sum_{\tau=\mathrm{t}}^{\tau=\mathrm{t}+\mathrm{T}} \frac{\mathrm{CN}(\tau)}{\mathrm{T}}
$$

ATFM の指標值と同じ時間間隔 $\mathrm{T}=30$ 分として 30 分間の平均管制機数 (average number of controlled aircraft in 30 minutes) を求める。例として T01（上 越) セクタの 10 分おきに求めた 30 分間の平均管制 機数を Fig.4の折れ線で示す。Fig.4 より指標値と 30 分間の平均管制機数は相関があることがわかっ た。

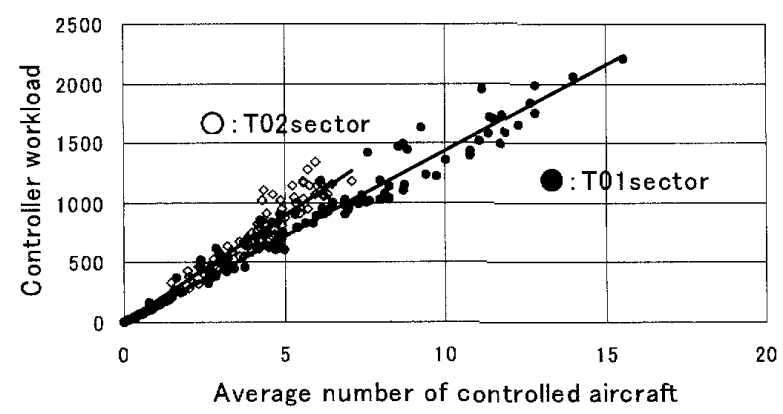

Fig.5 Current index (controller workload) to average number of controlled aircraft in 30 minutes 
T01（上越）セクタと T02（東北）セクタの指標 值と 30 分間の平均管制機数との相関関係を Fig.5 に示す。

各時刻の 30 分間の平均管制機数と指標值は $\mathrm{T} 01$ セクタだけでなく、T02 セクタでも比例することが わかった。比例係数は T02 セク夕のほうが大きい。 これは、同一機数を管制するとき、T02 セク夕の指 標値が大きい、つまり管制官の作業が大きいことを 意味している。

(1)式で求められる現行の指標值 TASKT $(\mathrm{t})$ は、30 分間の平均管制機数に対する近似係数 $A$ 、管制機数 $\mathrm{CN}(\mathrm{t})$ 、セク夕内飛行時問 $\mathrm{STT}_{\mathrm{T}}(\mathrm{t}, \mathrm{i})$ を用いて以下のよ うになる。

$$
\begin{aligned}
\operatorname{TASK}_{\mathrm{T}}(\mathrm{t}) & =\sum_{\mathrm{i}=1}^{\mathrm{N}} \mathrm{ST}_{\mathrm{T}}(\mathrm{t}, \mathrm{i}) \mathrm{C}_{\mathrm{ij}} \\
& \cong \mathrm{A} \sum_{\tau=\mathrm{t}}^{\tau=\mathrm{t}+\mathrm{T}} \frac{\mathrm{CN}(\tau)}{\mathrm{T}} \\
= & \frac{\mathrm{A}}{\mathrm{T}} \sum_{\tau=\mathrm{t}}^{\tau=\mathrm{t}+\mathrm{T}} \mathrm{CN}(\tau) \\
= & \frac{\mathrm{A}}{\mathrm{T}} \sum_{\mathrm{i}}^{\mathrm{N}} \mathrm{ST}_{\mathrm{t}}(\mathrm{t}, \mathrm{i}) \\
& \cong \frac{1}{N} \sum_{\mathrm{i}}^{\mathrm{N}} \mathrm{C}_{\mathrm{ij}} \sum_{\mathrm{i}}^{\mathrm{N}} \mathrm{ST}_{\mathrm{t}}(\mathrm{t}, \mathrm{i})
\end{aligned}
$$

セクタ内管制機数とセクタ内飛行時間の関係より (5)式亡(6)式は成り立つ。各セク夕の T (=30) 分間 の平均管制機数に対する指標値の近似係数 $\mathrm{A} の 1 / \mathrm{T}$ の值と第 4.2 節の各セクタのおける各分類の管制負 荷係数值 $\mathrm{C}_{\mathrm{ij}}$ の平均值を Fig.6 に示す。Fig.6より式 (7)が成り立つ。

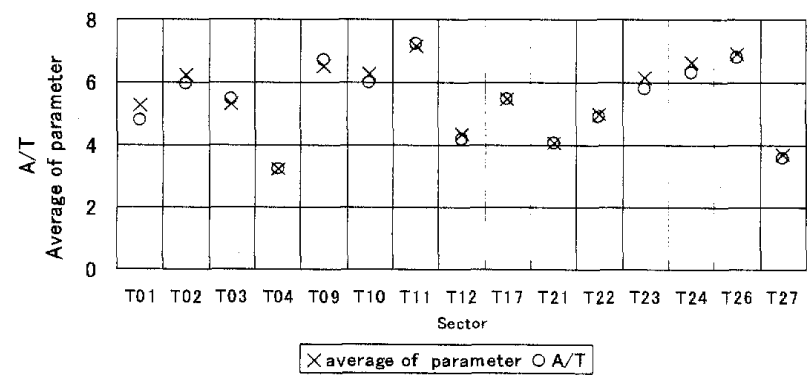

Fig.6 Approximation coefficient and average of parameter classified by category for each sector
15 セクタに㧍いて、ATFM の指標值である管制 作業量は 30 分間の平均管制機数に比例することが わかった。その比例定数は各セクタで異なることが わかった。平均管制機数が同じでも、T11（関東南 C）セクタが一番指標值が大きく、T04（関東東） セク夕が一番小さいことがわかった。

\section{5. 提案する指標}

\section{1 目的}

管制官の各航空機への管制作業の分析を行うこと なしに、交通流をもとにATFM の指標值を求めたい。 現行の指標値を求める際に利用する管制真荷係数が 同じ分類の航空機でも、その時の管制官や交通量に よって管制指示等の管制作業が異なる場合がある。 交通流をもとに、共通の係数をもとに指標值を求め たり。

管制官は航空機相互間に定められた管制間隔（航 空機同士の最低間隔）を保つように管制を行う。管 制（監視）をしている航空機に対して近接する航空 機（近接機）が堌加すると管制官は近接機と管制間 隔を確保するために監視する必要があり、管制指示 を出す場合もある。従って、現行の指標值を求める 際に利用する管制作業に基づく管制負荷係数は近接 機数と関係があると考えられる。

そこで、航空機の位置等から近接している航空機 の数（近接機数）に着目し、航空機 $\mathrm{a}_{\mathrm{i}}$ の近接機数 $\mathrm{PA}_{\mathrm{i}}$ とセク夕内飛行時間を用いて指標値を求める方 法を提案する。

\section{2 指標值の求め方}

セクタ内に航空機が多数存在しても全ての航空機 の近接機数が 0 の場合もある。この場合でも各航空 機に対してセクタの入出域地点でパイロットとの通 信や監視等の管制作業は生じる。指標值は、セクタ 内飛行時間に比例し、かつ航空機 $a_{i}$ の近接機数 $P A_{i}$ が増えるとさらに増えるので、係数としてパラメ一 夕 $\mathrm{K} （ \mathrm{~K}>0$ : 定数) を用いて、式(1)の管制作業を表 す係数 $\mathrm{C}_{\mathrm{ij}}$ を $\left(\mathrm{K}+\mathrm{PA}_{\mathrm{i}}\right)$ とした。 $\mathrm{PA}_{\mathrm{i}}$ の求め方は第 5.3 節で、 $\mathrm{K}$ の求め方は第 5.5 節で述べる。その結果求 められる值 TASK_P $\mathrm{T}(\mathrm{t})$ を式(8)のように提案する。

TASK $\_P_{T}(t)=\sum_{i=1}^{N} S T_{T}(t, i)\left(P_{i}+K\right)$

\section{3 近接機の定義}

今回は出域地点で航空機の位置等から近接する航 空機に着目し、セクタ内部での近接機については対 象としていない。航空機 $a_{i}$ のセクタの出域時刻 $\mathrm{OT}_{\mathrm{i}}$ 
における航空機の水平位置を $\left(\mathrm{X}_{\mathrm{i}}\left(\mathrm{OT}_{\mathrm{i}}\right) 、 \mathrm{Y}_{\mathrm{i}}\left(\mathrm{OT}_{\mathrm{i}}\right)\right)$ 、 高度を $\left(\mathrm{Z}_{\mathrm{i}}\left(\mathrm{OT}_{\mathrm{i}}\right)\right)$ とし、航空機 $\mathrm{a}_{\mathrm{j}}$ の出域時刻 $\mathrm{OT}_{j}$ における航空機の水平位置を $\left(\mathrm{X}_{\mathrm{j}}\left(\mathrm{OT}_{\mathrm{j}}\right) 、 \mathrm{Y}_{\mathrm{j}}\left(\mathrm{OT}_{\mathrm{j}}\right)\right)$ 高 度を $\left(\mathrm{Z}_{\mathrm{j}}\left(\mathrm{OT}_{\mathrm{j}}\right)\right)$ とする。航空機 $\mathrm{a}_{\mathrm{i}}$ において以下の条 件を同時に満たす便を近接機と定義した。

$$
\begin{aligned}
& \left|O T_{j}-O T_{i}\right| \leq M \\
& \left|Z_{j}\left(O T_{j}\right)-Z_{i}\left(O T_{i}\right)\right| \leq H
\end{aligned}
$$

$$
\sqrt{\left(\mathrm{X}_{\mathrm{i}}\left(\mathrm{OT}_{\mathrm{i}}\right)-\mathrm{X}_{\mathrm{j}}\left(\mathrm{OT}_{\mathrm{j}}\right)\right)^{2}+\left(\mathrm{Y}_{\mathrm{i}}\left(\mathrm{OT}_{\mathrm{i}}\right)-\mathrm{Y}_{\mathrm{j}}\left(\mathrm{OT}_{\mathrm{j}}\right)\right)^{2}} \leq \mathrm{D}
$$

航空交通管制では、安全を保ちつつ效率よく航空 機を運航するため、航空機相互間に管制間隔の基準 を設けている。国内の航空路の高さ力向の管制間隔 は $1,000 \mathrm{ft} （ 1 \mathrm{ft}=0.3048 \mathrm{~m}$ ）（同方向では $2,000 \mathrm{ft}$ ） で、水平方向の管制間隔は $5 \mathrm{NM}(1 \mathrm{NM}=1,852 \mathrm{~m})$ である。また出域地点では同高度の航空機の水平方 向の間隔は $20 \mathrm{NM}$ となっている。この点を考慮して 今回の近似条件は 5 分 (480knot で飛行する航空機 では $40 \mathrm{NM}$ に相当)、 $\mathrm{H}=2,000 \mathrm{ft} 、 \mathrm{D}=20 \mathrm{NM}$ とし た。(5,2000,20) は $\mathrm{M}=5$ 分、 $\mathrm{H}=2000 \mathrm{ft} 、 \mathrm{D}=20 \mathrm{NM}$ を示す。以下 $(\mathrm{M}, \mathrm{H}, \mathrm{D})$ で表す。(M,H,D) の值が 大きくなれば、近接機数が多くなる。

\section{4 出域便数之近接機数との関係}

各便の出域時刻をもとに時間帯ごとの便数を求め た。T01 セクタの各時間帯の出域便数を $(5,2000,20)$ の時の近接機の便数(number of proximity aircraft) $\mathrm{PA}_{\mathrm{i}}$ で区分してみた。T01 セクタを例として Fig.7 に示す。

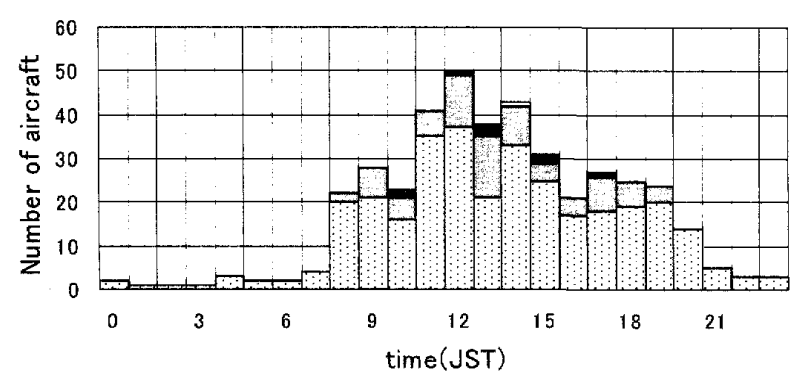

Number of proximity aircraft $\square 0 \square 1 \square 2 \square 3$

Fig.7 Number of aircraft passing over sector boundary (T01 sector)

T01 セクタにおいて一番便数が多い時間帯は 12 時で 50 便である。そのうち近接機が 2 便であった のが 1 便、近接機が 1 便であったのが 12 便で残り 37 便は近接機がなかった。T01 セクタでは、1 機あ たりの近接機数の平均值は 0.25 便であった。出域便 数が 1 時間あたり 15 便以下の時間帯では全ての航
空機で $\mathrm{PA}_{\mathrm{i}}$ が 0 であった。他のセクタでも同様に調 査してみる亡近接機数が多いのは T09 (関東西) 七 クタで、近接機の最大值は 6 便で、平均は 1.4 便で あった。

\section{5 現行の方法と提案方法の指標の比較}

T01 セク夕の出域地点での近接条件 $(5,2000,20)$ において近接機数を求め、(8)式でパラメータ K を変 化させて提案した指標値を求めた。現行の指標值で ある(1)式で求めた指標值と提案した指標值の相関 を Fig. 8 に示す。今回は $\mathrm{K}=3 、 4 、 5$ の 3 パターンを 示す。

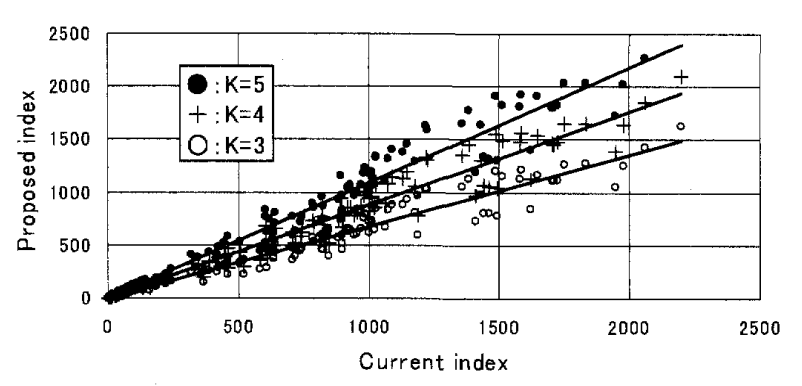

Fig.8 Relationship proposed index and current index (T01 sector)

Fig.8より現行の指標值と提案した指標値は $\mathrm{K}$ の 值にかかわらず比例関係があることがわかる。現行 の指標值と各 $\mathrm{K}$ に対する提案した指標値との回帰 式を求め、そのときの比例係数を求めた。この比例 係数が 1 のとき、現行の指標值と提案した指標值が ほぼ一致する。 $\mathrm{K}=3$ の時は比例係数が 0.6788、同様 に K=4 は $0.8847 、 \mathrm{~K}=5$ は 1.0906 であった。 $\mathrm{K}$ と 比例係数との関係より $\mathrm{T} 01$ セクタでは $\mathrm{K}=4.5$ のと き、比例係数が 1 となり現行の指標値と提案した指 標值がほぼ一致する。

Fig.9にT01 セクタの現行と提案した指標值を時 系列に示す。現行の方法による指標值を棒グラフに、 $(5,2000,20)$ の近接条件の時の近接機数を求め $\mathrm{K}=4.5$ のときの提案した指標值を折れ線グラフに示 す。

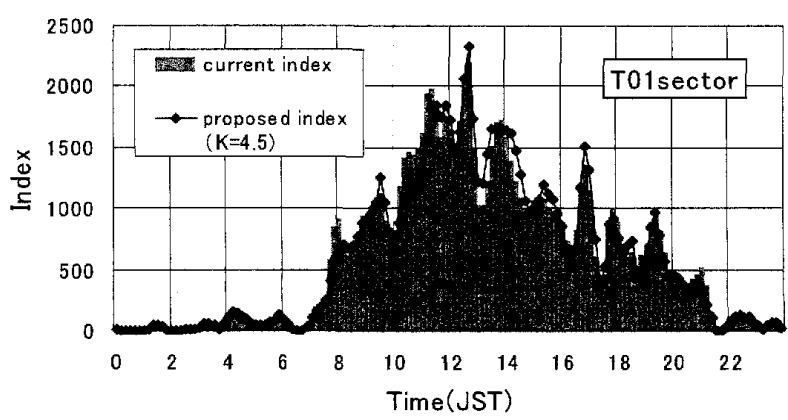

Fig.9 Each index (T01 sector) 
Fig.9 より時間推移がほぼ一致していることがわ かる。管制作業を分析せずに交通流をもとに指標值 が求められた。

15 セクタにおいて各々現行の指標值と提案した 指標値を比較して各セクタで $\mathrm{K}$ の值が求められた。 $\mathrm{K}$ をセクタによらずある值に設定、またはセクタの 特徵や交通流でいくつかの值に分類して設定したい と考え、今回は 1 日 (24 時間) 平均管制機数と $\mathrm{K}$ の関係に着目しその関係を Fig.10に示す。

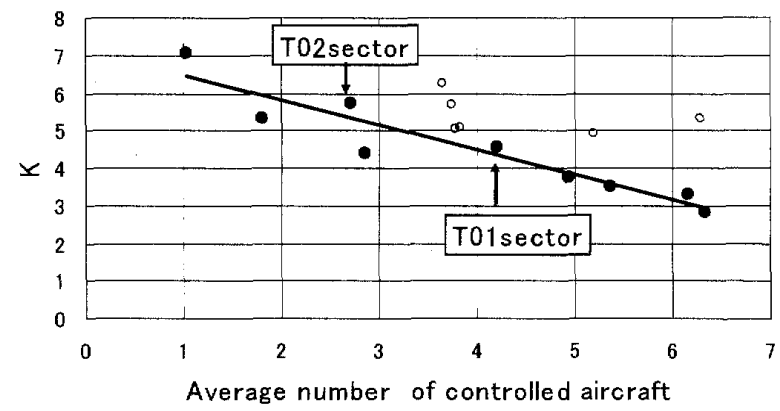

Fig. 10 Parameter $\mathrm{K}$ to average of controlled aircraft for each sector

(O : The number of arrival aircraft $\leqq 100$

$\bigcirc$ : The number of arrival aircraft $>100$ )

1 日の平均管制機数が 1.03 便と一番小さい $\mathrm{T} 11$ (関東南 $\mathrm{C}$ ) セク夕は $\mathrm{K}=7.1 、 1$ 日の平均管制機数 が 6.33 便と一番大きい $\mathrm{T} 04$ (関東東) セク夕は $\mathrm{K}=2.8$ と定められた。

Fig.2 より到着機の管制作業が多いため、到着機 が多いと指標値も大きくなると考えられる。各セク タの到着機数の 1 日あたりの平均值は 100 便であり、 100 便より少ないセクタにおいて K と平均管制機数 との関係の回帰式を求めたところ、一次式であるこ とがわかった。到着機数が多いセク夕は平均管制機 数と回帰式で求める值より指標值が大きいことがわ かる。

現行の指標值はセクタごとにパラメータを算出し なければならないが、近接条件を $(5,2000,20)$ に設 定し、到着機数が少ないセクタでは Fig.10より平均 管制機数と K の関係があることがわかった。その条 件下に㧍いては共通のパラメータで提案式を用いて 指標値を推定できることがわかった。

今後セク夕の交通流、特徵、近接条件等さらに調 査し指標值との関係を検討していきたい。

\section{6.まとめ}

航空交通管制において、安全で効率的な運航のた め航空交通流管理が実施されている。航空交通流管
理の指標値は、管制官の航空管制業務の分析に基づ く管制負荷係数を用いて求められる。東京航空交通 管制部の 15 セクタの航跡データにより現行の指標 值である管制作業量の時間推移を求めた。交通流と して管制機数を調査し、指標值との関係について調 ベた。現行の指標值は、30 分間の平均管制機数と比 例することがわかった。その比例係数は、管制負荷 係数の平均值であった。

管制作業を分析せずに交通流をもとに指標值を求 める方法として各航空機に近接する航空機数を利用 して求める方法を提案した。その結果、近接機数之 パラメータ $\mathrm{K}$ を用いて提案した指標值と現行の方 法で求めた指標値がほぼ一致した。各セクタでパラ メータ K の值は異なるが、 $\mathrm{K}$ の值は各セクタの 1 日 の平均管制機数と関係があることがわかった。

今後、セク夕の交通流、特徵等と指標値之の関係 についてさらに詳細に検討していきたい。近接機の 条件亡してセクタの出域地点だけでなく、セク夕内 での経路の交差地点にも着目したり、近接条件を複 数設定したりしていきたい。

\section{謝辞}

レーダデータの収集にご協力いただきました国土 交通省東京航空交通管制部の関係各位に感謝いたし ます。

\section{参考文献}

（1）福島幸子、福田豊、住谷美登里、瀬之口敦、 “高度変更量に着目した航空交通流管理における容 量值計算方法の検討”、平成 18 年度電子航法研究所 研究発表会講演概要、pp.27-32、平成 18 年 6 月

（2）(財)航空保安研究セン夕、“航空交通流管理に 㧍ける交通容量算定方式の高度化に関する調查報告 書”、2002.3

（3）住谷美登里、福岛幸子、福田豊、“近接航空機 数を考慮した管制作業量の予測”、電子情報通信学会 技術研究報告、SANE2007-52、2007.7

\section{兵疑庶答}

河合雅司（富山商船高専）:

近接機数を求める条件を、 5 分、2000ft、20 海 里 (NM) に設定された理由を教えてください。

\section{住谷美登里 :}

航空交通管制では、予め航空機間の最小間隔 （管制間隔）が定められており、例えば同一方 向での高さ方向の管制間隔基準は $2,000 \mathrm{ft}$ 亡な っています。また出域地点での同高度の航空機 
の水平方向は $20 \mathrm{NM}$ となっています。これらの

点を考慮して今回はこのように設定しました。 